\title{
COMPETENCIES FOR EDUCATIONAL ACTIVITIES IN NURSING
}

\author{
Valéria Marli Leonello ${ }^{1}$ \\ Maria Amélia de Campos Oliveira²
}

Leonello VM, Oliveira MAC. Competencies for educational activities in nursing. Rev Latino-am Enfermagem 2008 março-abril; 16(2):177-83.

The focus of this study is the interface between nursing education and nursing care in its educative dimension. Objective: To develop a profile of competencies for nursing care education from the perspective of the subjects involved. Method: Historical and dialectical materialism was used as the theoretical and methodological framework. Competence was addressed as the conceptual category, as defined by Perrenoud, based on healthcare concepts and on instrumental knowledge as advocated by Mendes-Gonçalves. Results: the analysis of empirical material resulted in the creation of 10 core competencies for nursing education activities. Conclusion: The need to give a new meaning to education action from the perspective of Popular Education implies the development of pedagogical opportunities during their undergraduate studies in order to enable students to use their knowledge and skills to develop a dialogical attitude of recognition of the subjects of nursing care.

DESCRIPTORS: education, nursing; competency-based education; professional competency; nursing care; health education

\section{COMPETENCIAS PARA LA ACCIÓN EDUCATIVA DE LA ENFERMERA}

Este estudio tiene como objetivo estudiar la interfase entre la enseñanza y la asistencia de enfermería, en su dimensión educativa. Objetivo: Construir un perfil de competencias para la acción educativa de la enfermera a partir de la perspectiva de los sujetos participantes. Método: Para el referencial teórico metodológico del materialismo histórico y dialéctico, se utilizó como categoría conceptual la noción de competencia definida por Perrenoud, con base en las concepciones del trabajo en la salud y en el saber operante de Mendes-Gonçalves. Resultados: El análisis del material empírico resultó en la construcción de diez competencias para acción educativa de la enfermera. Conclusión: La necesidad de dar un nuevo significado a la acción educativa, en la perspectiva de la Educación Popular, implica desarrollar las competencias mediante oportunidades pedagógicas que, durante la formación inicial, permitan a los estudiantes utilizar sus conocimientos y habilidades en pro de una actitud dialógica y de un reconocimiento de las necesidades de los sujetos asistidos.

DESCRIPTORES: educación en enfermería; educación basada en competencias; competencia profesional; atención de enfermería; educación en salud

\section{COMPETÊNCIAS PARA AÇÃO EDUCATIVA DA ENFERMEIRA}

Este estudo tem como objeto a interface entre o ensino e a assistência de enfermagem, em sua dimensão educativa. Objetivo: Construir perfil de competências para ação educativa da enfermeira, a partir da perspectiva dos sujeitos envolvidos. Método: No referencial teórico metodológico o materialismo histórico e dialético, e utilizouse como categoria conceitual a noção de competência definida por Perrenoud, ancorada nas concepções de trabalho em saúde e no saber operante de Mendes-Gonçalves. Resultados: A análise do material empírico, resultou a construção de dez competências para ação educativa da enfermeira. Conclusão: A necessidade de ressignificar a ação educativa, na perspectiva da Educação Popular, implicando o desenvolvimento de competências mediante oportunidades pedagógicas que, durante a formação inicial, permitam aos estudantes utilizar seus conhecimentos e habilidades em prol de atitude dialógica e de reconhecimento das necessidades dos sujeitos assistidos.

DESCRITORES: educação em enfermagem; educação baseada em competências; competência profissional; cuidados de Enfermagem; educação em saúde

${ }^{1}$ RN, Master's student, e-mail: valeria.leonello@gmail.com; ${ }^{2}$ RN, Assistant Professor, e-mail: macampos@usp.br. University of Sao Paulo, College of Nursing 


\section{INTRODUCTION}

$\boldsymbol{E}_{\text {ducational practices are part of the work in }}$ nursing care. Historically, these practices have emphasized giving information and changing behavior of individuals that were strongly connected with a health care model geared to diseases, focusing on technical scientific knowledge and fragmentation of health actions, therefore its authoritarian and coercive feature ${ }^{(1)}$. Because of that, these practices cannot meet health care demands of individuals, families and social groups because they do not consider social determination of the health-disease processes and they are not guided to encourage social subjects to face their problems ${ }^{(2)}$.

As a consequence, there is great distancing between educational projects developed by nurses in health services and care needs of the population. Nurses, in turn, complain about difficulties and lack of competency to develop educational practices with greater dialog and competence such as those defended by Popular Education ${ }^{(3-4)}$.

Initial education in nursing plays an essential role to form competencies for educational action of nurses. National Curriculum Guidelines (DCNs), in force since 2001, restate the need and the duty of Universities to form health professionals geared to the needs of SUS (National Health System), to adequate health education to the health needs of the Brazilian population ${ }^{(5)}$.

DCNs recommend that the education of all health professions must be guided by the principles and guidelines of the National Health System, to ensure total attention and quality and the humanization of care to meet health needs ${ }^{(5)}$.

In this sense, health education should be thought of in the perspective of Popular Education, considering that health practices and professional education must be based on principles and guidelines of the National Health System. Development of education actions in this perspective demands the development of specific competences, which is the objective of the present study.

\section{OBJECTIVES}

- Build a competence profile for education action of nurses as of the perspective of different individuals implied in the initial nursing education.
- Identify knowledge, skills, and attitudes for education action of nurses in their process of care.

\section{THEORY AND METHODOLOGY REFERENCE}

This is an exploratory and qualitative study using as theoretical and methodological reference the Historical and Dialectical Materialism (HMD), since it contributed to Nursing investigation and intervention, when it considered social phenomena as part of the reality.

Education action in health, under the perspective of Popular Education ${ }^{(3-4)}$ and Popular Education in Health ${ }^{(1-2)}$ was used as a base. Concept category adopted was the competency ${ }^{(6)}$, rooted on the conceptions of health work $^{(7)}$ e operating knowledge ${ }^{(7)}$.

Places of study

The places of study were: Nursing School of the University of São Paulo (EEUSP), and two health services connected to USP: the University Hospital (HU) and the Butantã School Health Center (CSEButantã).

Subjects*

Five groups of subjects took part in the study: group 1, formed by 5 professors of EEUSP; group 2, with 5 students finishing Nursing at EEUSP; group 3; with 10 assistant nurses, five of each service mentioned; group 4; with two managers, one from each service, and group 5, with 8 users, five from UH, and three from CSE-Butantã, totaling 30 participants.

\section{Approach techniques}

Focal group technique has been used with professors and students (groups 1 and 2) and the semi-structured interview with participants of groups 3,4 , and 5 .

Data analysis

To assess empirical material, speech analysis has been used ${ }^{(8)}$. The recorded and transcribed material of interviews and focal groups produced

* The research has been approved by the Ethical and Research committee of the places studied. Subjects were approached following Informed Consent, based on Regulation 196/96 of the National Health Council. 
discursive texts for each group approached. Texts were read and the extracts relevant for research were selected. Speeches selected were organized in thematic sentences which were organized according to the four principles of education ${ }^{(9)}$, for each approached group.

Last, skills and attitudes of all groups have been articulated and reorganized, on the light of the theoretical reference, in a picture of competencies for nursing education action.

\section{RESULTS}

Through the articulation among knowledge, skills, and attitudes from the speech of subjects, we could design a summarizing picture of the competencies for nursing education action, as of the perspective of individuals implied in initial nursing education, discussed next.

Table 1 - Syntheses of competences for nursing education action. São Paulo, 2007

\begin{tabular}{l}
\hline Foster integrality in health care \\
Link theory with practice \\
Foster user embracement and building bonds with individuals cared for \\
Consider themselves and work as agents that change health reality \\
Acknowledge and respect autonomy of individuals regarding their lives \\
Respecting common sense, acknowledging incompleteness of \\
professional knowledge \\
Use dialog as a strategy to transform reality in health \\
Operate pedagogical techniques that make dialog with individuals \\
possible \\
Give proper information to individuals \\
Value and practice communication with intersectoral approach in health \\
care
\end{tabular}

\section{DISCUSSION}

Foster integrality in health care

Education action in health, as a practice with dialog and participation, aims at changing the reality of health in individuals and social groups cared for. Considering the close relationship between care and health and integrality, it is advocated that integrality must be the guiding axis of education actions developed in health services ${ }^{(10)}$.

Integrality is seen as a "a principle in which actions regarding health are conducted, in the individual and collective level, trying to work in the determining factors that are connected with health, making sure that activities in health promotion, prevention and recovery are connected, in a multidisciplinary view that incorporate in practice the enlarged concept in health"(10).

The perspective of Popular Education in Health must be used since it values the knowledge of individuals, encourages dialog, participation, and changes in health reality, advocating that all health actions are education actions and, therefore, an action that is closer to integrality in health care, because it articulates activities of promoting, preventing and caring, as well as multi-professional work in different sectors.

Taking up integrality of care as a basis for developing education action with more dialog and participation, on the perspective of Popular Education in Health, implies that it should be adopted as guiding axis of the initial education.

Linking theory with practice - exercising praxis in health care

To foster integrality of care it is also necessary to link theory and practice, that is, knowledge and practice need to be constantly approximated, to build a real praxis in health care and in education practice. Speeches from group 1, formed by professors, emphasized the need to teach nursing students, future nurses, to exercise praxis in health care during their education.

Praxis is reflection and, at the same time, actions of men in the world to transform it, since "in a dialectic view, action and world, world and action, are closely related. However, action is only humane when doing comes together with reflecting"(4).

Furthermore, praxis is a process of actionreflection with the potential to change reality. Exercising it in health care, regarding education actions, implies making nursing work a reflexive practice, that questions and has potential to transform health reality and foster integrality of care.

Foster user embracement and building bonds with individuals cared for

The notion of user embracement adopted refers to the behavior towards user, that is, the attitude of professionals to users of services and their needs. In this sense, user embracement means to practice listening to health needs of individuals ${ }^{(11)}$. This 
perspective was translated into speeches of professors, nurses, students, and managers as a way to "recognize and know how to listen to health needs of individuals" and for users, as a way to "offer attention", to people during care.

Practice listening through user embracement demands that health professionals get involved and commit themselves to individuals and their needs. This involvement and commitment may be expressed by the bond. That is the reason for calling the competence "Fostering user embracement and building a bond with individuals cared for", since we understand that it is impossible to welcome health needs of individuals, listen to them, and understand them without getting involved.

Building bonds means to keep close and clear relations with individuals cared for, sympathizing with their suffering; facilitating building their autonomy; being responsible for their care and knowing how to relate and integrate with individuals, in health service and in the community ${ }^{(12)}$.

To perform education actions in health with more dialog and participation, health professionals, and nurses among them, must foster welcome and build bonds with individuals in their professional practice trying to understand, recognize, and fulfill their health needs.

Recognizing and working as an agent to transform health reality

According to the perspective of Popular Education, changing reality is only possible through actions of human beings, who should be the subjects and not objects of transformation.

In the health area, we may say that professionals facing reality of health care, observing and living with frequent dehumanization of care, poor condition of services, devaluation of human beings as health workers and users - develop a behavior that can be either critical and reflexive or conformed and acritical.

Several conditions are part of professional actions in the context of health services, in their conjunctions and structures. However, individuals cannot be neutral to the reality they are in. That is, they are either in favor of transformation and change or they support or accept things the way they are ${ }^{(3)}$.

Thinking about education action in health as a essentially transforming of the reality in health, which can only be done with the participation of individuals involved in it, health professionals must see themselves as agents to change this reality and so they can work in education practices that foster this situation.

This is a challenge for nursing since it is essentially a female profession, characterized by a practice historically connected with care, the social role of women. Nursing has a history of double subordination, social subordination, to the work of physicians; and gender subordination, to males ${ }^{(13)}$.

Thus, to see oneself as a transforming agent means, for nurses, among other challenges, to redefine their care practice, fighting for changing their social role and for the integrality of health care that is humane and meets the health demands of individuals.

Respect the autonomy of individuals regarding their ways of living life

Autonomy is understood here as the possibility for individuals to rebuild their sense of life, therefore, giving a new meaning to the way they live their lives ${ }^{(14)}$.

For users to build their autonomy, first they need, among other aspects, that health professionals respect and recognize them ${ }^{(15)}$. This attitude of respect regarding the autonomy of individuals is still uncomfortable for some health professionals. This is because some professionals think they can define how users must face their health problems since they have the technical and scientific knowledge, which is socially recognized.

Individuals cared for, because of their experiences, develop an understanding of the recommendations and actions of health services, and develop attitudes towards them. The every day practice of acknowledging and respecting the autonomy of people regarding the way they live their lives to restate the commitment with total and humane health attention and, therefore, as a guide for developing education actions in the services is one of the many challenges health professionals and nurses face.

Acknowledging and respecting the knowledge of the common sense, recognizing the incompleteness of professional knowledge

The term common sense comes from Philosophy and is related, overall, with knowledge 
from and for every day life. As it is built in the every day life, it is not socially legitimated.

The scientific knowledge, on the other hand, expressed by the professional knowledge, is legitimate for society and is, therefore, valid and must be spread.

In the history of health education practices in Brazil, valorization of scientific knowledge over the common sense contributed to a health care geared to the demands of services and their professionals rather than the needs of individuals cared for ${ }^{(1)}$.

Hierarchization between scientific knowledge and common sense also contributes for developing an omnipresent posture of health professionals who depreciate and disqualify common sense, because they have scientific knowledge. This posture towards the other makes health professionals not truly committed with individuals they care for and they get more distant from them ${ }^{(4)}$.

However, it is not the case of valuing one knowledge over the other, of course common sense has contradictions, uncertainties, limits and even prejudice, as well as the scientific knowledge, although the last is based on scientific "certainties" that are discussible.

To dialog, education action must acknowledge and respect as legitimate and valid common sense knowledge, generally subsumed to scientific knowledge in health care. To that end, we must assume that professionals do not know everything, and that does not mean giving up scientific knowledge or submitting it to the common sense. We must acknowledge that there are other kinds of knowledge and professional knowledge that is also incomplete is among them. It is in constant construction and therefore, needs to be redesigned, contextualized, confronted, and approximated to other kinds of knowledge especially that of common sense to become useful knowledge.

Using dialog as a strategy to change reality in health

Dialog is defined as a meeting of human beings for a common action. It is established as of 4 elements: love to the world of individuals, humbleness, faith in men, and critical thinking ${ }^{(4)}$.

If these bases are defended for the construction of dialog, there is the possibility of a horizontal pedagogical relationship, in which trust from the learners' side would be the consequence for the educators' side $^{(4)}$.
Historically, education action in health services more often legitimized technical and scientific knowledge, imposing it to the population, rather than trying to foster shared and participative dialog with these individuals searching for a common project to face health problems and meet health demands of individuals.

The experiences using the perspective of Popular Education as guiding methods for education in health services were a benchmark when they broke away from the traditional norms of the relations between professionals and users and built a more horizontal and participative relationship, making dialog a strategy for facing health problems and for transforming this reality ${ }^{(16)}$.

Develop pedagogic techniques that make dialog with individuals cared for viable

To use dialog as a strategy to transform health reality, nurses need to use pedagogical techniques, especially group techniques, defined as one "set of procedures that, applied to a group situation favor achieving group objectives with: cohesion, interaction, productivity, and group premiums"(17).

In the field of education practices in health, currently there is a great concern with the issue of group approach. The use of group technique is an important tool for nurses in education activities with collective individuals, especially those which adopt a pedagogic perspective with dialog and participation such as Popular Education in Health. Even so, it is seen that initial education of professionals in health area, including nursing, does not allow the development of competences regarding group techniques.

During initial education, nursing students need to be in contact with different group techniques, using knowledge and skills to conduct them in health services. However, it is necessary to understand them as means to reach a purpose and never as an end ${ }^{(17)}$. Group techniques may be used to foster and make dialog viable as a strategy for changing health reality.

Give individuals proper information

In the field of education practices, the inefficiency of "bank education", defined by Popular Education as a method in which educators "deposit" 
in learners information and knowledge scientifically proved has been shown since it does not consider the way of life of people and their view of their health.

The competency for giving individuals proper information refers to supplying necessary information to individuals so that they can reflect and make a critical analysis of their reality ${ }^{(3-4)}$.

However, how can health professionals use such knowledge in their education practice? Health professionals should have a "bag" with knowledge, and information, and use its content every now and then. We should point out, however, the risk of "emptying" all the content of the bag. Information should be used according to the needs of individuals ${ }^{(2)}$. Additionally, the content of the bag is not finished, ready, and complete. It can be built with individuals cared for.

Value and exercise engagement with intersectoral approach in health care

To overcome health problems of the Brazilian reality, characterized by complexity and diversity, we must recognize that health sector cannot solve alone and develop strategies to face this reality by shutting down in itself, in its knowledge and professionals.

It is increasingly urgent and necessary to value multidisciplinary work, that is, building partnerships with the different individuals involved and committed with a new health reality ${ }^{(18)}$.

Multidisciplinary work involves collective and organized action assuming respect to diversity and singularities of each subject, individual or collective, social or institutional. Therefore, we are closer to the understanding of dialogued education defended by

\section{REFERENCES}

1. Vasconcelos EM. Educação Popular nos Serviços de Saúde. 3a ed. São Paulo: Hucitec; 1997.

2. Valla VV. [Entrevista]. Trab Educ Saúde 2005;3(1):22738.

3. Freire P. Educação e mudança. Rio de Janeiro: Paz e Terra; 1979.

4. Freire P. Pedagogia do oprimido. 17 a ed. Rio de Janeiro: Paz e Terra; 1987.

5. Ministério da Educação (BR). Parecer CNE/CES 113/2001. Estabelece as diretrizes nacionais dos cursos de graduação em enfermagem, medicina e nutrição [página na Internet] Brasília; 2001 [citado 2005 abr. 10]. Disponível em: http:// www.mec.gov/ftp/ces/ces1133.doc

6. Perrenoud P. Construir as competências desde a escola. Porto Alegre: Artmed; 1999.
Freire, in which dialog and participation of individuals are necessary.

We know that heterogeneity and diversity of individuals, expressed in their interests and requirements, are elements that make multidisciplinary action a process practice, built when there is mutual recognition ${ }^{(18)}$.

\section{FINAL CONSIDERATIONS}

The profile of competences for education action of nurses shows the need for a new meaning of education action in health care, and this new meaning entails not only the context of education practices in Brazilian health history, but also the observation and assessment of these practices, trying to identify their possibilities and limits, similarities and differences, to make them closer to the perspective of Popular Education in Health.

With this change, education action will not be seen as an additional activity, performed in health services, but rather as a practice that base and redesign all health care.

We know that just building a profile of competences does not ensure renewal of education practices in health. We must invest in the discussion and reflection on the way this profile is ran in the routine of services and in nursing services ${ }^{(6)}$.

Building a profile of competences for education action in nursing in its process of care work is, therefore, one of the tasks of the initial education in nursing in the interface between teaching and process. The aim of this study was to contribute in this sense.

7. Mendes-Gonçalves RB. Tecnologia e organização social das práticas de saúde. São Paulo: Hucitec; 1994.

8. Fiorin JF. Elementos da análise de discurso. 9a ed. São Paulo: Contexto; 2000

9. Delors J, organizador. Educação: um tesouro a descobrir. $8^{a}$ ed. São Paulo: Cortez; 2003. (Relatório para a UNESCO da Comissão Internacional sobre Educação para o Século XXI). 10. Albuquerque PC, Stotz EN. A educação popular na atenção básica à saúde no município: em busca da integralidade. Interface Comun Saúde Educ 2004; 8(15):259-74.

11. Teixeira RR. Humanização e atenção primária à saúde. Ciênc Saúde Coletiva 2005;10(3):585-97.

12. Merhy EE. Em busca da qualidade dos serviços de saúde: os serviços de porta aberta para a saúde e o modelo tecnoassistencial em defesa da vida. In: Cecílio LCO, organizador. Inventando a mudança em saúde. São Paulo: Hucitec; 1994. p.116-60. 
13. Oliveira MAC. Da intenção ao gesto: a dialética da formação de enfermagem em saúde coletiva [tese livredocência]. São Paulo: Escola de Enfermagem, Universidade de São Paulo; 2004.

14. Cecílio LCO. As necessidades de saúde como conceito estruturante na luta pela integralidade e eqüidade na atenção em saúde. In: Pinheiro R, Mattos RA, organizadores. Os sentidos da integralidade na atenção e no cuidado à saúde. Rio de Janeiro: ABRASCO; 2001. p. 113-26.

15. Boemer MR, Sampaio MA. O exercício da enfermagem em sua dimensão bioética. Rev Latino-am Enfermagem 1997; $5(2): 33-8$.

16. Vasconcelos EM. Constituição, crise e redefinição da Educação Popular em Saúde [texto na Internet]. [s.d.] [citado 2005 jul 25]. Disponível em: http://redepopsaude.com.br/ Varal/ Concepcoes EPS/ConstituicaocriseEPS.PDF

17. Chaves AJF. Os processos grupais em sala de aula [texto na Internet]. Franca: UNESP; [s.d.]. [citado 2007 mar 10]. Disponível em: http://www.franca.unesp.br/oep/ Eixo\%203\%20\%20Te ma\%203.pdf

18. Rede Unida (Paraná). Divulgação em Saúde para Debate. Intersetorialidade na Rede Unida. [página na Internet]. [s.d.] [citado 2007 abr 16]. Disponível em: http:// www.redeunida.org.br/ producao/div_interset.asp 